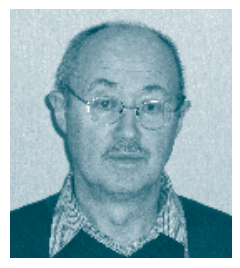

Iver Anker Strøm, farmasøyt, Sykehuset Innlandet HF. Divisjon Tynset.

\section{Legemidler bør påføres åpningsdato}

www.sykepleien.no

Les mer og finn litteraturhenvisninger på våre nettsider.

\section{Søkeord:}

) Legemidler

Kvalitet

Økonomi

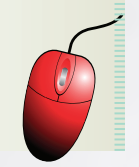

$\mathbf{S}$ osialdepartementet anbefalte for mange år siden å sette på apningsdato første gang man åpner emballasjen til enkelte egemidler og legemiddelformer (1). Dette gjelder for eksempel sterile legemidler som injeksjonsløsninger og øyedråper i flerdosebeholdere, samt linimenter som Klorhexidin vandig og spritløsninger. Holdbarhet etter åpning av sterile legemidler er beskrevet i Norske Legemiddelstandarder (2). Mange institusjoner har egne prosedyrer for hvilke legemidler som skal påføres anbruddsdato $(3,4)$. Jeg har målt i hvilken grad åpningsdato settes på der dette anbefales. I denne artikkelen vil jeg presentere resultatet av disse målingene.

\section{Materiale og metode}

Data ble samlet inn ved et legekontor og et lite lokalsykehus. Lokalsykehuset var representert ved to sengeavdelinger, en overvåkningsenhet og en poliklinikk. Resultatene er samlet i tabeller. Tabell 1 viser resultatene ved legekontoret og tabell 2 for lokalsykehuset. Ved lokalsykehuset ble data samlet inn en til to ganger i året fra og med april 2000 og til og med august 2010, og ved legekontoret en gang i året fra og med mai 2005 og til oktober 2010.

\section{Resultat}

På legekontoret ble det til sammen kontrollert 75 pakninger over fem år. Det var satt på dato på 21 pakninger. Av tabellen ser vi at det har vært en meget god utvikling. Første prøveuttak viste 0

TABELL 1: Legekontoret.

\begin{tabular}{|l|c|c|c|c|c|}
\hline Tema & 02.05 .05 & $\mathbf{0 4 . 0 9 . 0 6}$ & 13.09 .07 & 17.04 .09 & $\mathbf{0 8 . 1 0 . 1 0}$ \\
\hline Antall åpnet & 5 & 25 & 14 & 15 & 16 \\
\hline $\begin{array}{l}\text { Antall åpnings- } \\
\text { dato påsatt }\end{array}$ & 0 & 1 & 1 & 7 & 11 \\
\hline \% påsatt dato & $0 \%$ & $4 \%$ & $7 \%$ & $47 \%$ & $69 \%$ \\
\hline
\end{tabular}

TABELL 2: Lokalsykehuset. Samle tabell. 04.10 betyr april 2010 osv.

\begin{tabular}{|c|c|c|c|c|c|c|c|c|c|c|c|c|c|c|}
\hline Tema & 04.00 & 03.01 & 07.01 & 04.02 & 03.03 & 03.04 & 09.04 & 12.05 & 04.06 & 09.06 & 09.07 & 08.08 & 08.09 & 08.10 \\
\hline Antall åpning & 12 & 8 & 14 & 12 & 17 & 22 & 21 & 23 & 17 & 32 & 25 & 21 & 23 & 30 \\
\hline Antall åpningsdato påsatt & 11 & 7 & 8 & 7 & 12 & 19 & 13 & 17 & 10 & 23 & 17 & 14 & 15 & 20 \\
\hline \% påsatt dato & $92 \%$ & $88 \%$ & $57 \%$ & $58 \%$ & $71 \%$ & $86 \%$ & $62 \%$ & $74 \%$ & $72 \%$ & $68 \%$ & $67 \%$ & $59 \%$ & $65 \%$ & $67 \%$ \\
\hline
\end{tabular}

prosent påsatt dato og siste viste 75 prosent påsatt dato. Dette ga et gjennomsnitt på 28,0 prosent (tabell 1).

På sykehuset ble det til sammen kontrollert totalt 276 pakninger og 14 prøveuttak over en periode på elleve år. Det var satt på dato på 193 pakninger. Dette ga et gjennomsnitt på 69,9 prosent

Her ser vi ingen positiv utvikling. Tvert imot var resultatene best i begynnelsen av undersøkelsen.

Tabell 3 viser hvilke legemidler som var representert i undersøkelsen som ble foretatt den 8. oktober 2010 ved legekontoret.

Her ser vi at det kun godt kjente legemidler og legemidler som har vært lenge på markedet var representert. $\mathrm{NaCl} 9$ mg/ml 120 ble brukt til sårskylling og ikke blæreskylling.

Tabell 4 viser resultatet splittet opp i de enkelte legemidler for undersøkelsen ved sykehuset august 2010.

\section{Diskusjon}

Det var kjente og mye brukte legemidler som var involvert i målingen ved begge institusjonene. Ved det kommunale legekontoret var det relativt få pakninger involvert. Likevel viste resultatet av målingen at det har skjedd en tydelig og ønsket forbedring når det gjelder å sette dato på legemidlene ved åpning av emballasjen. Når det gjelder sykehuset er det derimot ikke mulig å se noen forbedring. Her er nivået stabilt litt lavt. Ved legekontoret ser vi også at mange pakninger av samme legemiddel var tatt i bruk. Hovedgrunnen til dette var mange brukssteder eller behandlingsrom.

Når dato ikke settes på ved åpning av emballasjen er det vanskelig å vurdere medikamentets kvalitet. Enkelte sykepleiere kasserer konsekvent legemidler der dato ikke er satt på. Dette gir økte utgifter i form av kassasjonskostnader, og merarbeid med økt innkjøp.

En viktig grunn til den positive utviklingen ved den kommu(tabell 2). 
TABELL 3: Alle legemidler ved siste gjennomgang som var den 08.10.10.

\begin{tabular}{|c|c|c|c|c|c|}
\hline Legemiddel & $\begin{array}{l}\text { Pak- } \\
\text { ning }\end{array}$ & Antall & $\begin{array}{c}\text { Del av pakning } \\
\text { som er igjen }\end{array}$ & $\begin{array}{l}\text { Utløps- } \\
\text { dato }\end{array}$ & $\begin{array}{l}\text { Påsatt } \\
\text { dato }\end{array}$ \\
\hline $\begin{array}{l}\text { Klorhexidin lini- } \\
\text { ment } 1 \text { mg/ml }\end{array}$ & $125 \mathrm{ml}$ & 1 & 0,8 & 20130431 & $07 \backslash 10 \backslash 10$ \\
\hline $\begin{array}{l}\text { Klorhexidin lini- } \\
\text { ment } 1 \mathrm{mg} / \mathrm{ml}\end{array}$ & $125 \mathrm{ml}$ & 1 & 0,9 & 20130431 & 0 \\
\hline $\begin{array}{l}\text { Klorhexidin lini- } \\
\text { ment } 1 \text { mg/ml }\end{array}$ & $125 \mathrm{ml}$ & 1 & 0,2 & 20130431 & 20.sep \\
\hline $\begin{array}{l}\text { Klorhexidinsprit } \\
\text { liniment } 5 \mathrm{mg} / \mathrm{ml}\end{array}$ & $125 \mathrm{ml}$ & 1 & 0,4 & 20120931 & 20.sep \\
\hline $\begin{array}{l}\text { Klorhexidinsprit } \\
\text { liniment } 5 \mathrm{mg} / \mathrm{ml}\end{array}$ & $125 \mathrm{ml}$ & 1 & 0,6 & 20110931 & 03.okt \\
\hline $\begin{array}{l}\text { Klorhexidinsprit } \\
\text { liniment } 5 \mathrm{mg} / \mathrm{ml}\end{array}$ & $125 \mathrm{ml}$ & 1 & 0,6 & 20110631 & 19.sep \\
\hline $\begin{array}{l}\text { Klorhexidinsprit } \\
\text { liniment } 5 \mathrm{mg} / \mathrm{ml}\end{array}$ & $125 \mathrm{ml}$ & 1 & 0,5 & 20110631 & 19.sep \\
\hline $\begin{array}{l}\mathrm{NaCl} \text { skyllevæske } \\
9 \mathrm{mg} / \mathrm{ml}\end{array}$ & $120 \mathrm{ml}$ & 1 & 0,9 & 20120531 & 0 \\
\hline $\begin{array}{l}\mathrm{NaCl} \text { skyllevæske } \\
9 \mathrm{mg} / \mathrm{ml}\end{array}$ & $120 \mathrm{ml}$ & 1 & 0,6 & 20130631 & 0 \\
\hline $\begin{array}{l}\text { Nacl skyllevæske } \\
9 \mathrm{mg} / \mathrm{ml}\end{array}$ & $120 \mathrm{ml}$ & 1 & 0,8 & 20130531 & 0 \\
\hline $\begin{array}{l}\text { NaCl skyllevæske } \\
9 \mathrm{mg} / \mathrm{ml}\end{array}$ & $120 \mathrm{ml}$ & 1 & 0,8 & 20120631 & 08.okt \\
\hline $\begin{array}{l}\text { Xylocain inj } 10 \\
\mathrm{mg} / \mathrm{ml}\end{array}$ & $10 \mathrm{ml}$ & 1 & 0,2 & 20120731 & 0 \\
\hline $\begin{array}{l}\text { Xylocain inj } 10 \\
\mathrm{mg} / \mathrm{ml}\end{array}$ & $20 \mathrm{ml}$ & 1 & 0,6 & 20121031 & $07>10 \backslash 10$ \\
\hline $\begin{array}{l}\text { Xylocain inj } 10 \\
\mathrm{mg} / \mathrm{ml}\end{array}$ & $20 \mathrm{ml}$ & 1 & 0,6 & 20120731 & 30.sep \\
\hline $\begin{array}{l}\text { Xylocain-Adr. inj } 10 \\
\mathrm{mg} / \mathrm{ml}+5 \mathrm{ug} / \mathrm{ml}\end{array}$ & $20 \mathrm{ml}$ & 1 & 0,5 & 20110731 & $07 \backslash 10 \backslash 10$ \\
\hline $\begin{array}{l}\text { Xylocain-Adr. inj } 10 \\
\mathrm{mg} / \mathrm{ml}+5 \text { ug/ml }\end{array}$ & $20 \mathrm{ml}$ & 1 & 0,2 & 20111031 & 29.sep \\
\hline Sum & & 16 & & & 11 \\
\hline
\end{tabular}

TABELL 4: Hvilke legemidler og antall av disse ved siste gjennomgang som var i august 2010.

\begin{tabular}{|l|c|c|c|}
\hline Legemiddel & Pakning & $\begin{array}{c}\text { Antall tatt } \\
\text { i bruk }\end{array}$ & $\begin{array}{c}\text { Antall på } \\
\text { satt dato }\end{array}$ \\
\hline Actrapid Penfill Novo & $3 \mathrm{ml}$ & 2 & 1 \\
\hline Heparin 100 ie & $10 \mathrm{ml}$ & 1 & 1 \\
\hline Insulatard FlexPen & $3 \mathrm{ml}$ & 2 & 1 \\
\hline Klorhexidin liniment 1 mg/ml & $125 \mathrm{ml}$ & 1 & 1 \\
\hline Klorhexidinsprit liniment $5 \mathrm{mg} / \mathrm{ml}$ & $125 \mathrm{ml}$ & 10 & 7 \\
\hline Klorhexidinsprit liniment $5 \mathrm{mg} /$ & $250 \mathrm{ml}$ & 2 & 0 \\
\hline ml farge & $10 \mathrm{ml}$ & 1 & 0 \\
\hline Mycomust inhalasjon & $20 \mathrm{ml}$ & 1 & 0 \\
\hline Nacl inj $9 \mathrm{mg} / \mathrm{ml}$ & $100 \mathrm{ml}$ & 2 & 2 \\
\hline NaCl inj $9 \mathrm{mg} / \mathrm{ml}$ plast htgl & $3 \mathrm{ml}$ & 2 & 2 \\
\hline Novorapid FlexPen & $100 \mathrm{ml}$ & 2 & 1 \\
\hline Sterilt vann inj plast htgl & $20 \mathrm{ml}$ & 1 & 1 \\
\hline Xylocain inj 10 mg/ml & $20 \mathrm{ml}$ & 3 & 3 \\
\hline Xylocain-Adr. inj 10 mg/ml + 5 ug/ml & & 30 & 20 \\
\hline Sum & & & 2 \\
\hline
\end{tabular}

nale enheten var at lederen der brukte resultatet av målingene til å sette fokus på datering av legemidler ved emballasjebrudd. Et legekontor har i tillegg få ansatte, lite skifte av personale og arbeider i hovedsak på dagtid og vanlige yrkedager. Derfor blir det lett å nå alle. Sykehuset er mer komplisert når det gjelder arbeidsforhold og tar også i mindre grad tak i slike data. For å

\section{Det bør voere en kvalitetsansvarlig på hver avdeling som sikrer at medikamentene dateres ved åpning.}

bedre dette bør det være en kvalitetsansvarlig på hver avdeling som sikrer at medikamentene dateres ved åpning. I første omgang bør et kvalitetsnivå på 80 prosent være innen rekkevidde for begge institusjonene. Men målet bør være å oppnå at 95 prosent av legemidlene dateres ved åpning.

\section{Konklusjon}

Målingene som er beskrevet i denne artikkelen, gir en god mulighet til å få oversikt over kvaliteten og til å vurdere virkningen av de tiltak som ble igangsatt. Slike data kan også gi et godt grunnlag for å fastsette kvalitetsnivået ved den enkelte institusjon. Hvilket kvalitetsnivå som er akseptabelt ved de enkelte prosesser bør utredes nærmere. For å oppnå forbedringer er det avgjørende at lederne bruker disse dataene aktivt. IIII

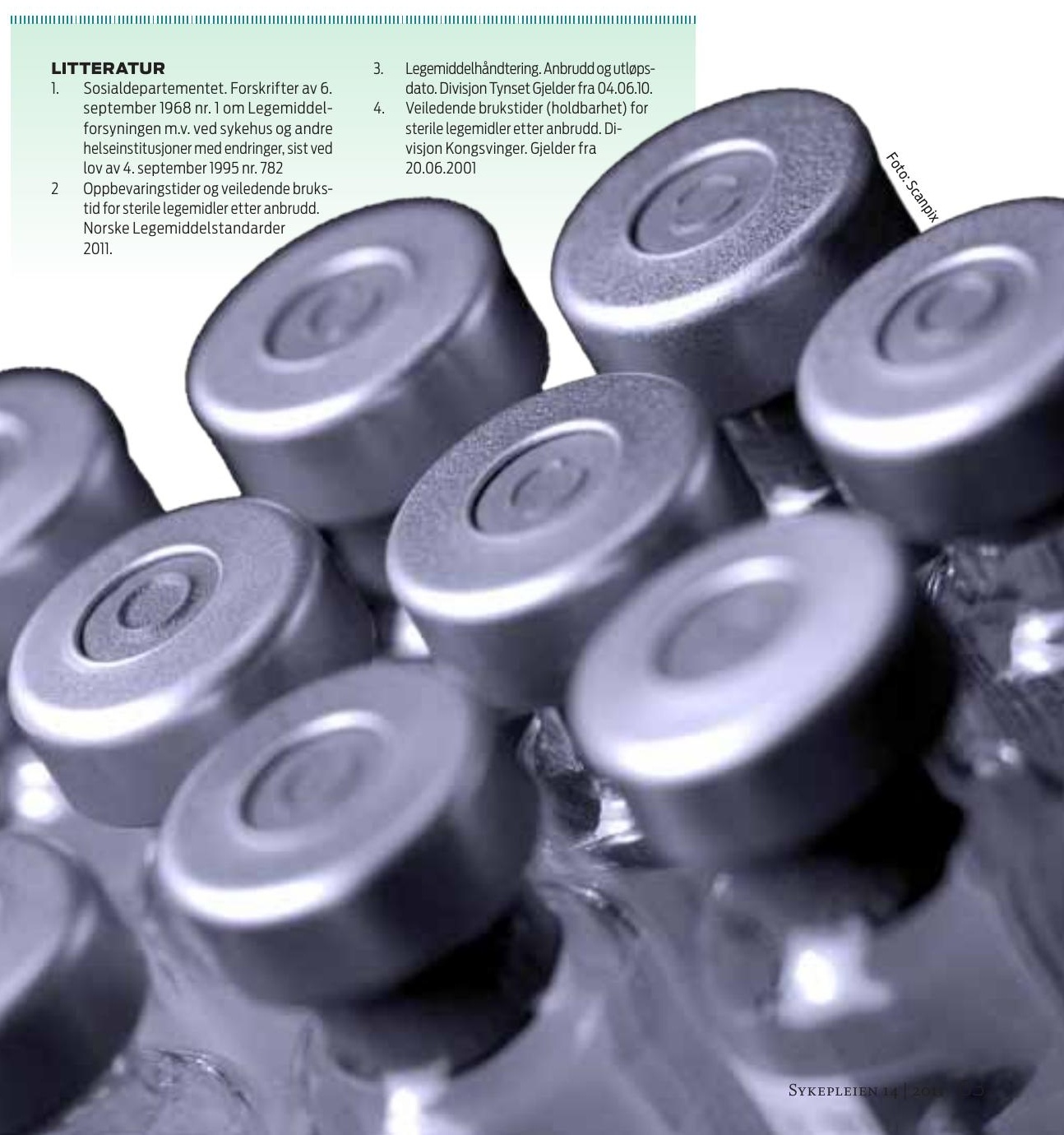

